\title{
Age, body posture, daily working load, past antihypertensive drugs and risk of hypertension: A rural Indonesian study
}

\author{
Bastaman Basuki*, Budhi Setianto†
}

\begin{abstract}
Abstrak
Sebagian besar penduduk Indonesia yang berjumlah 210 juta merupakan penduduk pedesaan. Hipertensi terdapat baik di kota maupun di desa, oleh karena itu terdapat penderita hipertensi yang cukup besar jumlahnya di pedesaan. Penelitian yang mengungkapkan faktor risiko hipertensi daerah pedesaan masih sedikit. Oleh karena itu, penelitian ini bertujuan untuk menentukan faktor risiko yang berkaitan dengan hipertensi di antara penduduk pedesaan. Data penelitian ini didapat dari hasil pengalaman lapangan mahasiswa tingkat-2 Fakultas Kedokteran Universitas Indonesia pada 12 Juli 2000 di pedesaan yang berbukit-bukit di Kecamatan Cijeruk, Bogor. Pemeriksaan tekanan darah dilakukan pada pukul 10:00 sampai 13:00. Subjek dipilih secara random dengan memakai klaster rukun tetangga. Wawancara dan pengukuran tekanan darah dilakukan di rumah subjek penelitian. Hasil penelitian menunjukkan bahwa penduduk berumur 40 tahun atau lebih mempunyai risiko yang lebih tinggi untuk menderita hipertensi dibandingkan dengan penduduk yang berumur 17.39 tahun, dan peningkatan risiko sangat mencolok di antara penduduk yang berumur $55-59$ tahun (rasio odds suaian $=21,62 ; 95 \%$ interval kepercayaan $(\mathrm{Cl})=4,10-113,97$ ). Dibandingkan dengan orang berpostur tubuh normal, orang yang gemuk mempunyai risiko hipertensi lebih dari enam kali lipat $(O R$ suaian $=6,33 ; 95 \%$ CI $=$ 2,62-15,29). Di samping itu, mereka yang putus minum obat antihipertensi mempunyai risiko hampir 12 kali lipat untuk menderita hipertensi. Akan tetapi, orang dengan beban kerja harian yang berat lebih terlidung terhadap hipertensi. Dari hasil penelitian ini dapat disimpulkan bahwa orang yang berumur lebih dari 40 tahun, yang putus pengobatan antihipertensi, dan orang yang tidak mempunyai beban kerja berat perlu mendapat perhatian terhadap kemungkinan menderita hipertensi. (Med J Indones 2001; 10: 29-33).
\end{abstract}

\begin{abstract}
Indonesia has about 210 million inhabitans and most of them live in rural areas, therefore in rural community it is estimated that a big number of hypertensive people can be found. However, few rural community-based studies have been conducted to identify hypertensive risk factors. This study aims to identify some risk factors related to hypertension in rural areas. The data for this study came from the result of the field study done by the second year medical students of the Faculty of Medicine, University of Indonesia. Jakarta. The study was conducted on July 12, 2000 at 10:00 AM to 1:00 PM in a rural area, the Cijeruk subdistrict in Bogor regency. The subjects were selected randomly using neighborhood cluster. Interviews and blood pressure were taken at the houses of the subjects. The results of this study showed that people aged 40 years or over had an increase risk to suffer hypertension compared to the 17-39 year old group, and the risk was most prominent among the 55-59 year group (adjusted odds ratio $=21.62 ; 95 \%$ confidence intervals $(C I)=4.10-113.97)$. Compared to the subjects with normal body posture, those who were obese had more than 6.3-folds increase in the risk to be hypertensive (adjusted $O R=6.33 ; 95 \% \mathrm{CI}=2.62-15.29$ ). In addition, those who discontinued antihypertensive drugs had almost 12-fold increase in the risk to be hypertensive relative to subjects who never take antihypertensive drugs (adjusted $O R=11.92 ; 95 \% C I=4.61-30.80$ ). This study concluded that special attention should be taken to the elderly aged 40 years and over, to some one who discontinued antihypertensive drugs, and whom had light daily working load to prevent hypertension.
\end{abstract} (Med J Indones 2001; 10: 29-33).

Keywords: hypertensive, risk factor, adjusted odds ratio, elderly.

At present Indonesia is in epidemiologic transition stage. Infectious diseases are still a major problem and at the time degenerative disorders such as hypertension is increasing in urban as well as in rural areas. ${ }^{1}$ However, governmental programs are still focusing on infectious diseases. There is no comprehensive community programs

\footnotetext{
* Department of Community Medicine, Faculty of Medicine University of Indonesia, Jakarta

† Department of Cardiology, Faculty of Medicine, University of Indonesia, Jakarta
}

to prevent degenerative diseases such as hypertension. The estimated prevalence of hypertension ranges from $5 \%$ to $15 \%$ among population aged 20 years or over. $^{2,3}$ Since Indonesia has about 210 million inhabitans and $70 \%$ of them live in rural area, ${ }^{1}$ it is estimated that in Indonesian rural community a big number of hypertensive people can be found. Some of them have stage 2 or 3 hypertension, and have to take antihypertensive drugs continuously. ${ }^{4}$ On the other hand, few rural community-based hypertensive studies have been conducted to identify the risk factors of hypertension in rural area. 
This study aimed to identify the risk factors related to stage 2 or 3 hypertension by collecting data from the inhabitans in a rural area, and measuring their blood pressure.

\section{METHODS}

This study was approved by the Ethical Committee of the Department of Community Medicine, University of Indonesia, Jakarta.

This study used a part of the data collected in the field study of the second year medical students of the Faculty of Medicine, University of Indonesia, Jakarta. The field study was conducted among the Sundanese ethnic group in a rural area, in Cijeruk subdistrict of Bogor regency, about $90 \mathrm{~km}$ southern of Jakarta, on July 12,2000 . We selected randomly 7 out of 18 villages. For each selected village, we selected 3 neighborhoods. Next, the first available 23 adults aged 17 years or above in each selected village were invited to participate in this study.

Interviews and blood pressure measurements were conducted at the houses of the subjects by the 160 specially trained second year medical students under close supervision by faculty members of the Faculty of Medicine, University of Indonesia. Each faculty member supervised 3-4 medical students.

The interview used a special questionaire form. The information collected was demographic characteristics (gender, age, education, job, social status, and working load). Furthermore, additional data about the last six month condition and habits in drinking, eating, eating vegetables and fruit, smoking, taking vitamin, having regular sport. In addition, data about the history of subject's and family past illness (hypertension, kidney disease, diabetes mellitus, thyroid disease), hormonal contraceptive use, antihypertensive drugs consumption, body weight fluctuation, and body posture were collected.

The time for measuring blood pressure was from 10:00 AM to 1:00 PM. Blood pressure measurements were done using mercury sphygmomanometer by the following techniques: ${ }^{4}$ the subject was seated in a chair with his/her back supported and his/her arms supported at heart level. Subjects were refrained from smoking and ingesting caffeine during the 30 minutes preceding the measurement. Measurement began after at least 5 minutes of rest. Both arms' systolic blood pressures (SBP) and diastolic blood pressure (DBP) were recorded. The SBP was recorded at the first appearance of sound (phase 1), and the disappearance of sound (phase 5) was used to define diastolic blood pressure (DBP). If the SDP was $140 \mathrm{~mm} \mathrm{Hg}$ or more, an additional measurement was done after about 5 minutes.

In this analysis we only analyzed the subjects having normal blood pressure, and stage 2 and 3 hypertension in order to identify some risk factors related to stage 2 or 3 hypertension. Therefore, the subjects who were taking antihypertensive drugs were excluded from this study.

Blood pressure normal was regarded normal or optimal when systolic blood pressure was less than $130 \mathrm{~mm} \mathrm{Hg}$ and diastolic blood pressure was less than $85 \mathrm{~mm} \mathrm{Hg}$. In this analysis we regarded the normal and optimal blood pressure as normal blood pressure. High normal pressure and stage 1 hypertension was diagnosed when systolic blood pressure was 130-139 $\mathrm{mmHg}$ and 140-159 mmHg or diastolic blood pressure was 85-89 $\mathrm{mmHg}$ and $90-99 \mathrm{mmHg}$, respectively. Stage 2 hypertension was diagnosed when systolic blood pressure was $160-179 \mathrm{mmHg}$, or diastolic blood pressure was $100-109 \mathrm{mmHg}$, while stage 3 hypertension was diagnosed when systolic blood pressure was more than $180 \mathrm{mmHg}$ or diastolic blood pressure was $110 \mathrm{mmHg}$ or more. ${ }^{4}$

The criteria for daily working loads were as follows: light daily working load if in general the tasks could be done in sitting or standing position, such as in clerks, house hold activities; moderate daily working load if the tasks resulted in an increase in breathing frequencies or sweating, such as in barbers; and heavy working load if the tasks needed muscles' activity which always resulted in the increase in both breathing frequencies and sweating, such as in blue color labor. 5

Body postures (normal, skinny, and obese) were judged based on the student perception who examined the subjects.

Family status were categorized into three groups namely pre-prosperous, prosperous, and prosperous plus. This category was a simplified version of the Indonesia National Family Planning Coordinating Board's definition on family status. ${ }^{6}$

Pre-prosperous family were those who had only one of the following conditions. Condition I: the family members had a set of new clothes during the last year; 
Condition II: all family members aged 6-12 years attended schools; Condition III: all members of the family usually had meals at least two times a day; and condition IV: all family members did their religious activity.

Prosperous family were those who had the above four conditions, and prosperous plus family were those that met the prosperous family criteria, and the head of the family or a family member was active in an organization, a foundation, or other institution.

Statistical analyses were done using STATA 5.0 software. ${ }^{7}$ A number of risk factors were examined whether they were potential confounders and/or effect modifiers. Unconditional logistic regression analysis ${ }^{8}$ was used in order to determine the confounding effects and to determine the risk factors for hypertension. A risk factor was considered to be a potential confounder if in the univariate test it had a $P$-value < 0.25 which would be considered as a candidate for the multivariate model along with all known risk factors for hypertension. ${ }^{9}$ Confounders were estimated by the method of maximum likelihood. Ninety-five percent confidence intervals were based on the standard error of coefficient estimates. Relative risks represented by odds ratios (OR) were estimated by the methods of maximum likelihood.

\section{RESULTS}

A number of 490 subjects participated in this study. For this study we excluded 17 subjects who were taking antihypertensive drugs, 71 subjects with high normal hypertension and 83 subjects with stage 1 hypertension. There were 263 subjects with normal blood pressure and 56 subjects with stage 2 or 3 hypertension who were included in the analysis. Hypertensive and optimal/normal subjects were similarly distributed with respect to the last six months habits on drinking, and vegetable and fruit consumption.

Table 1 shows that hypertensive and normal blood pressure subjects were similarly distributed with respect to gender, education, profession, and family status. Hypertensive subjects were more likely to be divorced, widows or widowers compared to normal blood pressure subjects. However, hypertensive subjects having daily moderate and hard working loads were less than those with normal blood pressure.
Table 1. Some demographic characteristic of subjects and risk of hipertension

\begin{tabular}{|c|c|c|c|c|c|c|}
\hline & \multicolumn{2}{|c|}{$\begin{array}{l}\text { Normal } \\
(\mathrm{N}=263)\end{array}$} & \multicolumn{2}{|c|}{$\begin{array}{l}\text { Hyper- } \\
\text { tension } \\
(\mathrm{N}=56) \\
\end{array}$} & \multirow{2}{*}{$\begin{array}{l}\text { Crude } \\
\text { odds } \\
\text { ratio }\end{array}$} & \multirow{2}{*}{$\begin{array}{c}95 \% \\
\text { confidence } \\
\text { intervals }\end{array}$} \\
\hline & $\mathrm{n}$ & $\%$ & $\mathbf{n}$ & $\%$ & & \\
\hline \multicolumn{7}{|l|}{ Gender } \\
\hline Male & 79 & 30.0 & 17 & 30.4 & 1,00 & Reference \\
\hline Female & 184 & 70.0 & 39 & 69.6 & 0.98 & $0.13-1.85$ \\
\hline \multicolumn{7}{|l|}{ Marital status } \\
\hline Manied & 232 & 88.2 & 43 & 76.8 & 1.00 & Referent \\
\hline Unmarried & 21 & 8.0 & 1 & 1.8 & 0.26 & $0.03-1.96$ \\
\hline Divorced & 8 & 0.8 & 3 & 5.3 & 8.09 & $1.31-44.88$ \\
\hline Widow/widower & 8 & 3.0 & 9 & 13.1 & 6.07 & $2.22-16.61$ \\
\hline \multicolumn{7}{|l|}{ Education } \\
\hline Illiterate/Read only & 48 & 18.3 & 18 & 32.1 & 1.00 & Reference \\
\hline Primary school & 123 & 46.8 & 26 & 46.4 & 0.56 & $0.28-1.12$ \\
\hline Junior high school (HS) & 44 & 16.7 & 5 & 8.9 & 0.33 & $0.10-0.89$ \\
\hline Senior HS or university & 41 & 15.6 & 6 & 10.7 & 0.39 & $0.14-1.08$ \\
\hline Unknown & 7 & 2.6 & 1 & 1.8 & 0.38 & $0.04-3.32$ \\
\hline \multicolumn{7}{|l|}{ Profession } \\
\hline None & 147 & 65.9 & 30 & 53.5 & 1.00 & Reference \\
\hline Laborer & 42 & 16.0 & 5 & 8.9 & 0.58 & $0.21-1.60$ \\
\hline Stall/self employment & 26 & 9.9 & 9 & 16.1 & 1.70 & $0.72-3.98$ \\
\hline Employee & 17 & 6.4 & 3 & 5.4 & 0.86 & $0.24-3.14$ \\
\hline Retired & 7 & 2.7 & 3 & 5.4 & 2.10 & $0.51-8.59$ \\
\hline Unknown & 24 & 9.1 & 6 & 10.7 & 1.23 & $0,46-3.25$ \\
\hline \multicolumn{7}{|l|}{ Working load } \\
\hline Light & 50 & 19.0 & 19 & 3.3 .9 & 1.00 & Reference \\
\hline Moderate & 171 & 650 & 32 & 57.2 & 0.49 & $0.26-0.94$ \\
\hline Hard & 42 & 16.0 & 5 & 8.9 & 0.51 & $0.11-0.91$ \\
\hline \multicolumn{7}{|l|}{ Family status } \\
\hline Pre-prosperous & 77 & 29.3 & 18 & 32.1 & 1.00 & Reference \\
\hline Prosperous & 97 & 369 & 24 & 42.9 & 1.05 & $0.54-2.09$ \\
\hline Prosperous plus & 89 & 33.8 & 14 & 25.0 & 0.67 & $0.31-1.44$ \\
\hline
\end{tabular}

In this analysis we could not prove that smoking habit increased the risk of hypertension. In addition, there was no evidence that those who had the habit to consume onion, or any vitamins, and to have regular sport for the last 6 months had a lower risk of hypertension compared with those who had not (Table 2).

Table 2. Smoking habit, garlic and vitamin consumption, sport, and risk of hypertension

\begin{tabular}{|c|c|c|c|c|c|c|}
\hline & \multicolumn{2}{|c|}{$\begin{array}{l}\text { Normal } \\
(\mathrm{N}=263)\end{array}$} & \multicolumn{2}{|c|}{$\begin{array}{l}\text { Hyper- } \\
\text { tension } \\
(\mathrm{N}=56)\end{array}$} & \multirow[t]{2}{*}{$\begin{array}{l}\text { Crude } \\
\text { odds } \\
\text { ratio }\end{array}$} & \multirow[t]{2}{*}{$\begin{array}{c}95 \% \\
\text { confidence } \\
\text { intervals }\end{array}$} \\
\hline & $\mathrm{n}$ & $\%$ & $\mathbf{n}$ & $\%$ & & \\
\hline \multicolumn{7}{|l|}{ Smoking } \\
\hline Never & 166 & 63.1 & 38 & 62.9 & 1.00 & Reference \\
\hline Past & 13 & 4.9 & 4 & 7.1 & 1.21 & $0.36 \cdot 4.50$ \\
\hline Current & 84 & 32.0 & 14 & 25.0 & 0.72 & $0.37-1.44$ \\
\hline \multicolumn{7}{|c|}{ Eating garlic } \\
\hline Never & 235 & 89.4 & 46 & 82.1 & 1.00 & Reference \\
\hline Past & 8 & 3.0 & 0 & 0 & N/A & - \\
\hline Current & 20 & 7.6 & 10 & 17.9 & 2.55 & $1.12-5.81$ \\
\hline \multicolumn{7}{|c|}{ Taking any vitamin } \\
\hline Never & 123 & 46.8 & 28 & 50.0 & 1.00 & Reference \\
\hline Past & 72 & 27.4 & 21 & 37.5 & 1.28 & $0.68-2.42$ \\
\hline Current & 68 & 25.8 & 7 & 12.5 & 0.45 & $1.19-1.09$ \\
\hline \multicolumn{7}{|l|}{ Sport } \\
\hline Never & 155 & 58.9 & 36 & 64.3 & 1.00 & Reference \\
\hline Past & 34 & 12.9 & 3 & 5.3 & 0.38 & $0.11-1.31$ \\
\hline Current & 74 & 28.2 & 17 & 30.4 & 0.99 & $0.52-1.88$ \\
\hline
\end{tabular}


Furthermore, in this study there was no evidence that family history and subject's history of diseases (kidney, diabetes mellitus, thyroid) increased the risk of hypertension.

Table 3. History of some diseases and risk of hypertension

\begin{tabular}{|c|c|c|c|c|c|c|}
\hline & \multicolumn{2}{|c|}{$\begin{array}{c}\text { Normal } \\
(\mathrm{N}=263)\end{array}$} & \multicolumn{2}{|c|}{$\begin{array}{l}\text { Hyper- } \\
\text { tension } \\
(\mathrm{N}=56)\end{array}$} & \multirow[t]{2}{*}{$\begin{array}{l}\text { Crude } \\
\text { odds } \\
\text { ratio }\end{array}$} & \multirow[t]{2}{*}{$\begin{array}{c}95 \% \\
\text { confidence } \\
\text { intervals }\end{array}$} \\
\hline & $\mathrm{n}$ & $\%$ & $n$ & $\%$ & & \\
\hline \multicolumn{7}{|c|}{ Kidney disease } \\
\hline Never & 238 & 90.5 & 48 & 85.7 & 1,00 & Reference \\
\hline Past & 10 & 3.8 & 3 & 5.4 & 1.49 & $0.39-5.61$ \\
\hline Current & 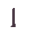 & 0.4 & 1 & 1.8 & 4.96 & $0.30-80.65$ \\
\hline Unknown & 14 & 5.3 & 4 & 7.1 & 1.42 & $0.45-4.49$ \\
\hline \multicolumn{7}{|c|}{ Diabetes mellitus } \\
\hline Never & 255 & 96.0 & 52 & 92.8 & 1,00 & Reference \\
\hline Past & 2 & 0.8 & 1 & 1.8 & 2.45 & $0.22-27.54$ \\
\hline Current & 0 & 0 & 1 & 1.8 & N/A & - \\
\hline Unknown & 6 & 2.3 & 2 & 3.6 & 1.64 & $0.32-8.32$ \\
\hline \multicolumn{7}{|c|}{ Thyroid disease } \\
\hline Never & 258 & 98.1 & 54 & 96.4 & 1,00 & Reference \\
\hline Past & 3 & 1.1 & 1 & 1.8 & 1.59 & $0.16-15.60$ \\
\hline Unknown & 2 & 0.8 & 1 & 1.8 & 2.39 & $0.21-26.82$ \\
\hline
\end{tabular}

Table 4. Family history of some diseases and risk of hypertension

\begin{tabular}{|c|c|c|c|c|c|c|}
\hline & \multicolumn{2}{|c|}{$\begin{array}{l}\text { Normal } \\
(\mathrm{N}=263)\end{array}$} & \multicolumn{2}{|c|}{$\begin{array}{l}\text { Hyper- } \\
\text { tension } \\
(\mathrm{N}=56)\end{array}$} & \multirow[t]{2}{*}{$\begin{array}{l}\text { Crude } \\
\text { odds } \\
\text { ratio }\end{array}$} & \multirow[t]{2}{*}{$\begin{array}{l}95 \% \\
\text { confidence } \\
\text { intervals }\end{array}$} \\
\hline & $\pi$ & $\%$ & $\mathrm{n}$ & $\%$ & & \\
\hline \multicolumn{7}{|c|}{ Hypertension } \\
\hline None & 178 & 62.7 & 37 & 66,1 & 1,00 & Reference \\
\hline Yes & 74 & 28.1 & 17 & 30.4 & 1.11 & $0.59-2.09$ \\
\hline Unknown & 11 & 4.2 & 2 & 3.5 & 0.87 & $0.19-4.11$ \\
\hline \multicolumn{7}{|c|}{ Kidney disease } \\
\hline None & 240 & 91.3 & 51 & 91.1 & 1,00 & Reference \\
\hline Yes & 15 & 5.7 & 3 & 5.3 & 0.94 & $0,26-3.37$ \\
\hline Unknown & 8 & 3.0 & 2 & 3.6 & 1.18 & $0.24-5.70$ \\
\hline \multicolumn{7}{|c|}{ Diabetes mellitus } \\
\hline None & 248 & 92.4 & 5 & & 1.00 & Reference \\
\hline Yes & 15 & 5.7 & 2 & & 0.61 & $0.14-2.75$ \\
\hline Unknown & 5 & 1.9 & 1 & & 0.92 & $0.10-8.01$ \\
\hline \multicolumn{7}{|l|}{ Struma } \\
\hline None & 251 & 95.4 & 52 & 92.8 & 1,00 & Reference \\
\hline Yes & 9 & 3.4 & 3 & 5.4 & 1.61 & $0.42-61.5$ \\
\hline Unknown & 3 & 1.2 & 1 & 1.8 & 1.61 & $0.16-15.77$ \\
\hline
\end{tabular}

Our final model on the relationship between risk factors and hypertension was shown on Table 5. This model indicates that subjects aged 40 years or over had an increase risk to be hypertensive compared with the subjects aged 17-39 years. The age group who had the most prominent hypertensive risk was the age group of 55-59 years. This age group had almost 13folds increase in the risk to be hypertensive (adjusted odds ratio $(\mathrm{OR})=21.62 ; 95 \%$ confidence intervals
$(C I)=4.10-113.97)$. The older sub-groups $(60-64$ years and 65-84 years) had more than 10 time and 5.6 time increase in the risk to be hypertensive, respectively.

Compared to normal body posture subjects, those who were obese had more than six-time increase in the risk to be hypertensive (adjusted $\mathrm{OR}=6.33 ; 95 \% \mathrm{CI}=$ 2.62 - 15.29). Additionally, those who discontinued antihypertensive drugs had almost 12 time increase in the risk to be hypertensive relative to subjects who never take antihypertensive drugs (adjusted OR = 11.92; 95\% CI: 4.61-30.80).

Table 5. Relationship between age group, body posture, daily working load, past hypertension medication and risk of hypertension

\begin{tabular}{|c|c|c|c|c|c|c|}
\hline & \multicolumn{2}{|c|}{$\begin{array}{l}\text { Normal } \\
(N=263)\end{array}$} & \multicolumn{2}{|c|}{$\begin{array}{l}\text { Hyper- } \\
\text { tension } \\
(\mathrm{N}=56)\end{array}$} & \multirow{2}{*}{$\begin{array}{l}\text { Adjus- } \\
\text { ted } \\
\text { odds } \\
\text { ratio }\end{array}$} & \multirow[t]{2}{*}{$\begin{array}{l}95 \% \\
\text { confidence } \\
\text { intervals }\end{array}$} \\
\hline & $\bar{n}$ & $\%$ & 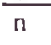 & $\%$ & & \\
\hline \multicolumn{7}{|l|}{ Age gгоuр } \\
\hline $17-39$ years & 167 & 63.5 & 12 & 21.4 & 1.00 & Reference \\
\hline $40-49$ years & 60 & 22.8 & 17 & 31.4 & 4.31 & $1.74-10.69$ \\
\hline $50-54$ years & 15 & 5.7 & 8 & 14.3 & 5.47 & $1.59=18.79$ \\
\hline $55-59$ years & 4 & 1.5 & 6 & 10.7 & 21.62 & $4.10-113.97$ \\
\hline $60-64$ years & 10 & 3.8 & 5 & 8.9 & 10.39 & $2.36-45.78$ \\
\hline $65-84$ years & 7 & 2.7 & 8 & 14.3 & 5.65 & $1.07-29.88$ \\
\hline \multicolumn{7}{|l|}{ Body posture } \\
\hline Normal & 158 & 60.1 & 20 & 35.7 & 1,00 & Reference \\
\hline Skinny & 72 & 27.4 & 12 & 21.4 & 0.81 & $0.31-2.14$ \\
\hline Obese & 33 & 12.5 & 24 & 42.9 & 6.33 & $2.62-15.29$ \\
\hline \multicolumn{7}{|c|}{ Daily working load } \\
\hline Light & 50 & 19.0 & 19 & 33.9 & 1.00 & Reference \\
\hline Moderate & 171 & 65.0 & 32 & 57.2 & 0.54 & $0.22-1.29$ \\
\hline Heavy & 42 & 16.0 & 5 & 8.9 & 0.22 & $0.06-0.88$ \\
\hline \multicolumn{7}{|c|}{$\begin{array}{l}\text { Past antihyper- } \\
\text { tensive medication }\end{array}$} \\
\hline Never & 247 & 93.9 & 33 & 58.9 & 1,00 & Reference \\
\hline Ever & 16 & 6.1 & 23 & 41.1 & 11.92 & $4.61-30.80$ \\
\hline \multicolumn{7}{|c|}{ * Adjusted each other for variables listed on this table } \\
\hline
\end{tabular}

There are several limitations that must be considered in the interpretation of our findings. Our analysis is limited to several factors only, and no laboratory test was performed. This study was conducted in a rural area within three hours, and involving 160 medical students, therefore we did not able to provide enough weighting scales to measure body weight. In addition, the blood pressure were measured by second-year medical students who did not have enough experience in taking blood pressures. 
In spite of the these limitations, the second-year medical students had passed physiology class and had been specially trained for this study, and they were supervised closely by the faculty members on sites when they measured blood pressures and interviewed the subjects.

Our data shows that obesity is one of the risk factors for hypertension. This finding is similar with other studies in Indonesia, ${ }^{2,3,5}$ as well as in developed countries. ${ }^{4,10}$ However, at the same area where the study was conducted, some people considered that one of the benefit of being a family planning acceptors was gaining body weight. ${ }^{11}$ The poor rural people wanted to have an appearance of wealthy people, such as obesity. This misleading opinion need to be corrected in order to prevent hypertension.

In addition, our results show that compared with those who had light daily working load, those with moderate and heavy daily working load got a better protection against hypertension. This finding is similar with the other studies. ${ }^{2,4,5,10}$

Our data also reveals that discontinuation of antihypertensive drugs increases the risk of hypertension. This finding is similar with the other studies. ${ }^{2,4,510}$ Therefore, hypertensive people need to be given counseling on hypertensive treatment to prevent discontinuation of hypertensive medication in hypertensive subjects.

In term of gender and education level, there was no difference in the risk to be hypertensive, and these findings are in accordance with the other studies in Indonesia. ${ }^{2,5}$

Our final model reveals that compared with the subjects aged 17-39 years, subjects aged 40 years or over had an increase risk to be hypertensive, and the risk was most prominent among the subjects aged 5559 years. The older age-groups (60-64 years and 6584 years) had relatively decreased risk to be hypertensive. This phenomena is analog to the healthy worker survivor effect. ${ }^{12}$ Those who had a better physical, mental, and other conditions had the ability to survive. In addition, some elder people (60 years or older) had been passed away of other diseases. Therefore, the older people who had better health condition were less likely to be hypertensive.

In conclusion, special attention should be paid to elderly aged 40 years and over, whom discontinued antihypertensive drugs, and had light daily working load, to prevent hypertension.

\section{Acknowledgment}

The authors thank all subjects, the local leaders, and second year medical students of the Faculty of Medicine, University of Indonesia, who cooperatively participated in this study. Special thanks to the Faculty members who were in charge as on site field supervisors for their high dedication. And lastly, to Dr. Astrid B. Sulistomo to review the earlier drafts of this manuscript that improved the final product.

\section{REFERENCES}

1. Department of Health of the Republic of Indonesia. Health profile on Indonesia 1999. Jakarta: The Department; 2000.

2. Boedi-Darmojo R. Epidemiology of hypertensive in Indonesia. In: Boedi-Darmojo R, Ed. Boedi-Darmojo's Papers. Semarang: University of Diponegoro; 1994.p.27587.

3. Boedi-Darmojo R, Setianto B, Sutedjo, Kusmana D, Andradi, Supari F, et al. A study of baseline risk factor for coronary heart diseases. Results of population screening in a developing country. Rev Epidem et Sante Publ 1990; 38:487-91.

4. National Heart, Lung and Blood Pressure Institute. The sixth report of the joint national committee on prevention, detection, evaluation and treatment of high blood pressure. Nat Inst Hith Publ No. 98-4084. Bethesda: The Institute; 1997.

5. Jakarta Monica Team. Monica community hypertension pattern. In: Sutedjo, Setianto B, Boedi-Darmojo R, Editors. Presentation and discussion on Jakarta Monica II survey 1993. Jakarta: Center for National Health on Heart; 1994. p.78-98.

6. State Ministry for Population/National Family Planning Coordinating Board. Dictionary on population terminology. Jakarta: The Ministry; 1997.

7. StataCorp. Stata statistical software: Release 5.0. Texas: College station; 1995.

8. Breslow NE, Day NE. Statistical Methods in Cancer Research. Vol I. The analysis of case-control studies. IARC Sci Publ No.32. Lyon: International Agency for Research on Cancer; 1980.

9. Hosmer DW, Lemeshow S. Applied logistic regression. New York: John Willey \& Sons; 1989.

10. Frohlich ED. Hypertension. In: Pearson TA, Criqui MH, Lupker RV, Oberman A, Winston M, editors. Primer in prevention epidemiology. Dallas: American Heart Association; 1994.p.131-42.

11. Basuki B. Improvement system on contraceptive choice at Cijeruk sub district. Jakarta: National Family Planning Coordinating Board / The Population Council; 1996.

12. Arrighi HM, Hertz-Piciotto I. The evolving concepts of the healthy worker survivor effect. Epidemiol 1994;5;186-96. 